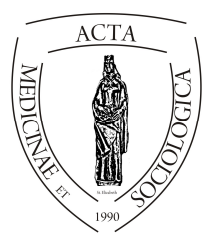

\title{
Foglalkoztatási helyzetkép és a munkával való elégedettség jellemzői
}

\author{
R. Fedor Anita ${ }^{1}$ \\ ${ }^{1}$ főiskolai tanár, Debreceni Egyetem Egészségügyi Kar, Szociális és Társadalomtudományi Intézet, Társadalomtu- \\ dományi Tanszék. Nyíregyháza, Sóstói út 2-4.
}

\section{INFO ABSTRACT}

\section{R. Fedor Anita \\ fedor.anita@foh.unideb.hu}

labor market, employment, job satisfaction, regional differences

\section{Keywords}

\begin{abstract}
Employment situation and job satisfaction characteristics. The central role of work is indisputable, it is a safety factor that determines the present status and future of the individual and his/her family. Lack of work over a period of time creates a series of problems. The employment situation in Hungary has moved in a positive direction since 2013, however, the level of employment and labor market mobility is not the same in different regions of the country.
\end{abstract}

The characteristics and opinions of the inhabitants of Nyíregyháza using the Quality of Life in Nyíregyháza research series are presented. The results of the 2018 analysis is discussed in detail and compared to data using the same instrument collected over the past 10 years. The authors compared the employment situation between 2008 and 2018 and found an improvement in Nyíregyháza.

Kulcsszavak
munkaeröpiac,
foglalkoztatás,
munka körülményeivel
kapcsolatos elégedettség,
regionális különbségek
\begin{abstract}
Absztrakt. A tanulmány Szabolcs-Szatmár-Bereg megyeszékhelyén, a Nyíregyházán élő lakosok gazdasági aktivitási jellemzőit mutatja be. Vizsgálatunkban a nyíregyházi városlakók munkavállalással, foglalkoztatással kapcsolatos alapadatait, véleményét elemezzük a Nyíregyháza Életminősége kutatássorozatban használt kérdőív alapján, melyben a gazdasági aktivitás feltérképezéséhez összesen 38. kérdést fogalmaztunk meg. A legutóbbi adatfelvétel alapját képező kérdőív gazdasági aktivitást mérő kérdéseinek összeállításánál figyelembe vettük az International Social Survey program témánk szempontjából releváns kérdéseit. Ezek a kérdések elsősorban a munkával, munkavállalással kapcsolatos értékekre, attitüdökre fókuszálnak.

A vizsgálat eredményeink azt mutatják, hogy javult a nyíregyháziak foglalkoztatási helyzete 2008 és 2018 . között.
\end{abstract}

Ez a tanulmány a Nyíregyháza város életminősége - Háztartáspanel kutatás Egészségi állapot felmérése keretében készült. 


\section{Bevezetés}

A munka központi szerepet tölt be a társadalom, a gazdaság és az egyén életében. A fogalom különböző megközelítései szerint a munka a szükségletek kielégítésének eszköze, a kultúra alapja, a társadalmi részvétel formája, a társadalmi beágyazódás alapja, a szükségletek kielégítésének eszköze (Móré, 2018). A legfontosabb, minden a továbbiakban felsorolt tényezőt magába foglaló jellemző a biztonság. A munka és itt elsősorban a munkahelyen végzett, illetve a bérrel és szolgáltatásokkal elismert társadalmi szerepére utalva - a modern társadalmakban biztonságot jelent.

Elsősorban azért mert a munkavégzésből származó jövedelem biztosítja a megélhetés alapvető feltételeit. A munka nélkül élőknek mindemellett számos a munkavégzéshez, mint feltételhez kapcsolódó szolgáltatások, ellátások (társadalombiztosítás) hiányával kell számolniuk.

A munkaerőpiaci generációs különbségekre fókuszáló kutatások azt feltételezik, hogy a fiatalabb életkori csoportok munkavállalói kevésbé elkötelezettek bizonyos „hagyományos” munkaerőpiaci értékek iránt, szemben a sokat dolgozó baby boomerek-kel. Azonban a külföldi keresztmetszeti és longitudinális vizsgálatok inkább generációs hasonlóságokat tártak fel a generációs különbségekkel szemben. (Hajdu és Sik, 2016) Mindez megerősíti a munka társadalmának globális jelenlétét, jelentőségét.

Más aspektusból vizsgálva a munkanélküliség hatással lehet az egyén szubjektív és a fizikai egészségi állapotára. Egy nemzetközi kutatás szerint egy munka nélkül lévő személynek 28\%-kal nagyobb a kockázata annak, hogy megromlik az egészségi állapota. Az egészségmegromlás kockázata nem érinti egységesen a különbözö korcsoportokat. Az időseknél gyengébb, a fiataloknál erősebb egészségkárosító hatással kell számolni. (Cooper et al 2008) A szerzők szignifikáns kapcsolatot találtak a szocioökonómiai státusz és az egészségi állapot, valamint a halandósági ráta között.

A munkából származó jövedelem, a munkahely által biztosított társas környezet ahhoz is hozzájárul, hogy az egyén részt tudjon venni olyan tevékenységekben, amely a társadalom tagjainak többsége számára megszokott.

A jövedelem hiánya - még ha közvetve is, de - hatást gyakorol a gyermek későbbi iskolai teljesítményére. Coleman (1996) szerint a családi háttér három összetevőjének egyike a család jövedelmi-, vagyoni helyzetét magába foglaló pénzügyi tőke, mely oly módon segíti a teljesítményt, hogy forrást biztosít olyan eszközök és szolgáltatások megvásárlásához melyek segítségével a gyerekek jobb iskolai teljesítményt érhetnek el. Amennyiben a pénzügyi tőke hiányos, úgy az akár a gyermek iskolai teljesítményének rovására mehet. Mindezek alapján nem kétséges, hogy a munka hiánya nehézségek sorozatát rója az egyénekre, családokra az élet számos területén.

Írásunkban nem térünk ki a fent említett munkával, gazdasági aktivitással összefüggő területek mindegyikének elemzésére. A kapcsolódó területek bemutatása Huszti Éva, Fábián Gergely, Takács Péter, Szoboszlai Katalin és Jávorné Erdei Renáta prezentálásában olvasható. (Huszti és mtsai, 2018; Szoboszlai, 2018; J. Erdei, Takács, 2018; Huszti, 2018; Fábián és mtsai, 2018) 


\section{Módszer}

Jelen írás Szabolcs-Szatmár-Bereg megyeszékhelyén, a Nyíregyházán élő lakosok gazdasági aktivitási jellemzőit mutatja be. A helyi foglalkoztatási adottságok részletes elemzése előtt rövid kitekintés olvasható a vizsgált megyeszékhely tágabb társadalmi és gazdasági környezetének föbb adottságairól, mintegy összemérve a lokális adatokat a megyei és regionális és az országos adatokkal.

Ezt követően a nyíregyházi városlakók munkavállalással, foglalkoztatással kapcsolatos alapadatait, véleményét elemezzük a Nyíregyháza Életminősége kutatássorozatban használt kérdőív alapján, melyben a gazdasági aktivitás feltérképezéséhez összesen 38. kérdést fogalmaztunk meg. A legutóbbi adatfelvétel alapját képező kérdőív gazdasági aktivitást mérő kérdéseinek összeállításánál figyelembe vettük az International Social Survey program témánk szempontjából releváns kérdéseit. Ezek a kérdések elsősorban a munkával, munkavállalással kapcsolatos értékekre, attitüdökre fókuszálnak.

Írásunk utolsó részében a panel vizsgálat müfajának köszönhetően összehasonlító elemzés olvasható a 2008, 2010, 2012, 2015 és 2018. évi adatok felhasználásával. Ezáltal megfigyelhetjük, hogy tíz év távlatában hogyan alakultak a nyíregyházi lakosok gazdasági aktivitási jellemzői.

Az elemző munkánkban az SPSS 24.00 for Windows szoftvert használtunk, melynek segítségével egy- és többváltozós elemzési technikákat alkalmaztunk. Előbbi segítségével átfogó képet kaptunk az adatbázisról, utóbbiak alkalmazása lehetővé tette két vagy több változó közötti összefüggések feltárását.

Az elemzés során a leggyakrabban használt többváltozós elemzési formák közé tartozott a kereszttábla-elemzés. A két változó közötti összefüggés bemutatására a Pearson-féle $\chi^{2}$ statisztikát alkalmaztunk.

\section{Foglalkoztatási helyzetkép}

A foglalkoztatási helyzet egyre kedvezőbb képet mutat Magyarországon. A pozitív irányú elmozdulás 2013-tól kezdődően figyelhető meg, mikor is az ország elkezdett kilábalni a 2008-as pénzügyi válság okozta gazdasági, foglalkoztatási sokkból. A kedvező irányú elmozdulás mellett azonban az is megfigyelhető, hogy a foglalkoztatás (KSH, 2017) és munkaerőpiaci mobilitás (Sebők 2013; 2015) mértéke nem egyformán alakul az ország különböző régióiban, megyéiben. Az is szembetünő, hogy a javuló tendencia ellenére a nők és férfiak foglalkoztatása közötti rés megmaradt.

A munkanélküliségi adatokat tekintve azt látjuk, hogy az országosan mért 4,2\%-hoz képest a regionális mutató 3,2\%-kal magasabb. A régió belső munkanélküliségi struktúráját vizsgálva az tapasztalható, hogy bár Jász-Nagykun-Szolnok és Hajdú-Bihar megye mutatója is meghaladja az országos szintet, viszont a magát regionális szinten legrosszabbul pozícionáló Szabolcs-Szatmár-Bereg megye több mint kétszeres munkanélküliségi rátája $(8,5 \%)$ országos viszonylatban is a legutolsó helyre szorítja. (1. ábra) 


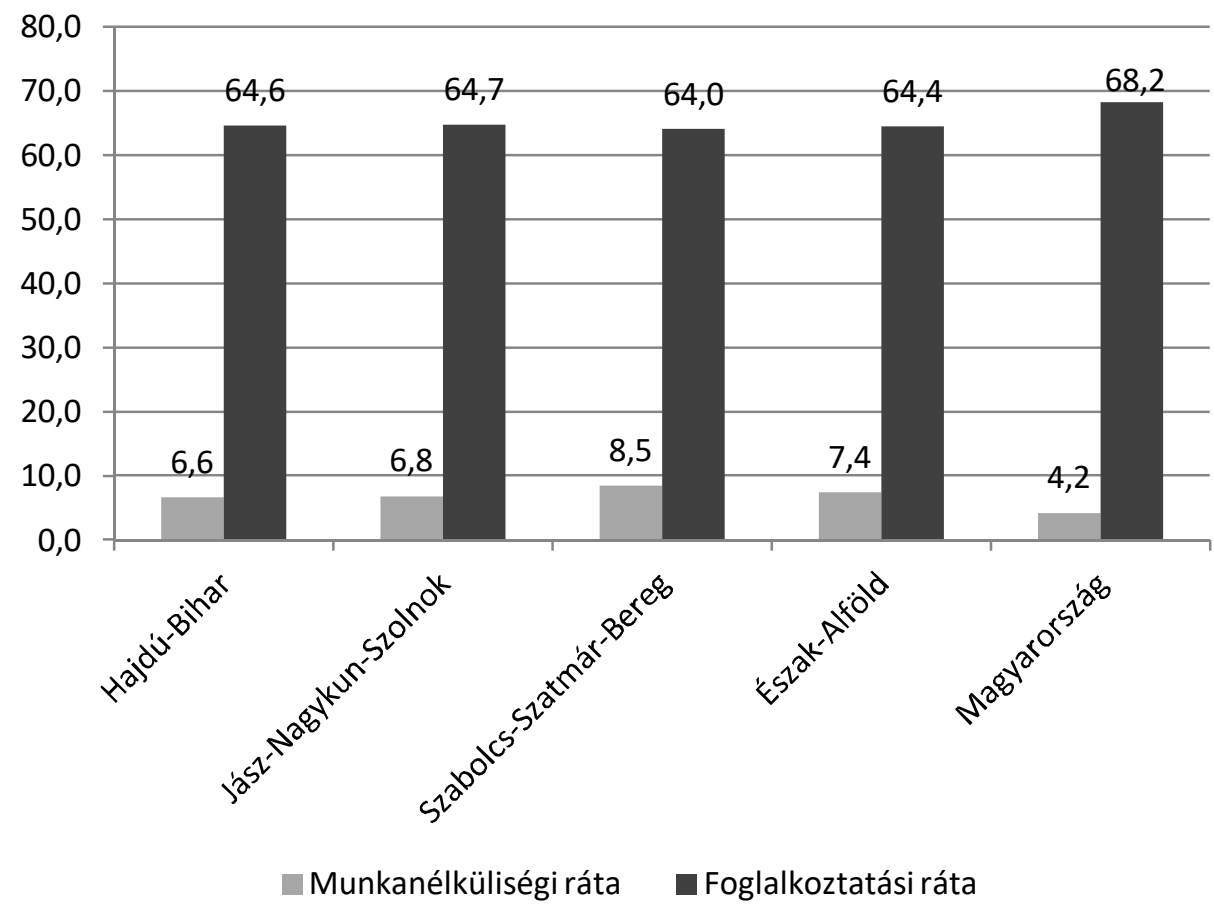

Forrás: http://www.ksh.hu/docs/hun/xstadat/xstadat_eves/i_qlf031.html

1. ábra. Foglalkoztatási, munkanélküliségi ráta a 15-64 éves népesség, 2017.

A 2008-as pénzügyi válság végzetes változást indított el a fejlett országokban. A pénzpiac összeomlása közvetlen hatást gyakorolt a munka világára. Magyarország foglalkoztatási mutatói a rendszerváltozáskor mért mélypontra kerültek. A munkaerőpiaci válság 2013-tól kezdődően mérséklődött, ekkor a foglalkoztatottsági színvonal meghaladta az 58,1\%-ot. Az ezt követő időszakban - javarészt a foglalkoztatáspolitika aktív eszközeinek köszönhetően - folytatódott a 2013-ban elkezdődött tendencia, s a legfrissebb (2017) adatok már 68,2\%-os foglalkoztatási rátát mutatnak. A vizsgálatok rámutattak arra, hogy a kedvező tendencia hátterében többek között a közmunka programok munkanélkülieket felszívó hatása áll. Ezek nélkül a foglalkoztatási és munkanélküliségi ráta valószínüleg rosszabb lenne. Emellett még érdemes megemlíteni: vannak olyan kistelepülések - ezek közül szeretném kiemelni az Észak-alföldi régióban található Szabolcs-Szatmár-Beregmegye egyes településeit-, ahol a közmunkából származó jövedelem jelenti az egyetlen munkavégzéshez kötődő legális jövedelmet, s mint ilyen, létfontosságú a rendkívül bizonytalan életkilátásokat mutató családok számára. Más oldalról a közmunkához tartozó jövedelem meg sem közelíti a nyílt munkaerőpiacon múködő jövedelmeket.

Bár Szabolcs-Szatmár-Bereg megye munkanélküliséggel való érintettsége egyértelmüen kedvezőtlen országos viszonylatban, mégis érdemes megemlíteni, hogy öt év távlatában több mint 7\%-os csökkenés tapasztalható e tekintetben megje- 
gyezve, hogy a közmunka és a foglalkoztatottság pontos arányát ez az adat nem mutatja. (1. táblázat)

\begin{tabular}{|c|c|c|c|c|c|}
\hline \multirow{2}{*}{ Területi egység } & \multicolumn{5}{|c|}{ Munkanélküliségi ráta \% } \\
\cline { 2 - 6 } & 2013 & 2014 & 2015 & 2016 & 2017 \\
\hline Észak-Alföld & $\mathbf{1 4 , 2}$ & $\mathbf{1 1 , 8}$ & $\mathbf{1 0 , 9}$ & $\mathbf{9 , 3}$ & $\mathbf{7 , 4}$ \\
\hline Hajdú-Bihar & 14,9 & 12,9 & 11,3 & 8,6 & 6,6 \\
\hline Jász-Nagykun-Szolnok & 11,3 & 7,6 & 7,1 & 6,6 & 6,8 \\
\hline Szabolcs-Szatmár-Bereg & $\mathbf{1 5 , 7}$ & $\mathbf{1 3 , 6}$ & $\mathbf{1 3 , 0}$ & $\mathbf{1 1 , 6}$ & $\mathbf{8 , 5}$ \\
\hline Országos & $\mathbf{1 0 , 2}$ & $\mathbf{7 , 7}$ & $\mathbf{6 , 8}$ & $\mathbf{5 , 1}$ & $\mathbf{4 , 2}$ \\
\hline
\end{tabular}

Forrás: http://www.ksh.hu/docs/hun/xstadat/xstadat_eves/i_qlf031.html

1. táblázat. Munkanélküliségi ráta az Észak-alföldi régióban (15-64 éves népesség).

Magyarországra a foglalkoztatottság és munkanélküliség tekintetében nagymértékü területi különbségek jellemzők, ami szintén hasonló a nemzetközi tendenciákhoz. A legrosszabb helyzetủ megyék közé tartozik Szabolcs-Szatmár-Bereg-, Hajdú-Bihar-, Borsod-Abaúj-Zemplén -, és Nógrád megye, a legkedvezőbbek közé pedig GyőrMoson-Sopron-, Vas-, Fejér- és Pest megye. Régiók tekintetében az Észak-Alföld és az Észak-Magyarország, Dél-Dunántúl régióit sújtja leginkább a munkanélküliség, a legkevésbé érintett terület pedig a Nyugat- és Közép-dunántúli régiók. Az egyes megyéken belül is differenciálódik a kisebb térségek helyzete, amely a megfelelőnek mondható infrastruktúra hiányából adódó megközelíthetőség különbségeire is viszszavezethető (KSH, 2016).

A területi egyenlőtlenségek csökkentését akadályozza, hogy a legalacsonyabb végzettségüek általában a legrosszabb helyzetü megyékben találhatók. Az országos összehasonlítás szerint az Észak-alföldi régióhoz tartozó Szabolcs-Szatmár-Bereg megyében a legrosszabb a népesség iskolázottságának megoszlása a 25-50 éves korcsoportban (Varga 2015). Következménye, hogy napjaink társadalmának, gazdaságának egyik legnagyobb problémája a halmozottan hátrányos helyzetü térségek fiataljainak az alacsony szintü iskolázottsága, az ebből következő munkaerőpiaci készségek hiánya (Láczay, 2017).

\section{A nyíregyházi lakosok foglalkoztatási jellemzői}

A 2018-as lekérdezés gazdasági aktivitásra vonatkozó adatai kedvező képet mutatnak. A megkérdezettek 68,1\%-a dolgozott 31,9\%-a pedig nem dolgozott a felmérés idején. Különösen igaz ez az elmúlt 4 adatfelvétel eredményei tükrében. 2008 és 2018 között több mint 13\%-kal, 2015-höz képest közel 14\%-kal nőt azok aránya, akik úgy nyilatkoztak, hogy dolgoztak a megkérdezés idején. Ez a növekedés hason- 
ló az országos tendenciához, azonban az is igaz, hogy a megyei adat jelenleg is az országos rangsor végén áll.

\begin{tabular}{|c|c|c|c|c|c|}
\hline & $\mathbf{2 0 0 8}$ & $\mathbf{2 0 1 0}$ & $\mathbf{2 0 1 2}$ & $\mathbf{2 0 1 5}$ & $\mathbf{2 0 1 8}$ \\
\hline Igen & $54,9 \%$ & $54,5 \%$ & $57,1 \%$ & $54,0 \%$ & $\mathbf{6 8 , 1 \%}$ \\
\hline Nem & $45,1 \%$ & $45,5 \%$ & 42,9 & $46,0 \%$ & $\mathbf{3 1 , 9 \%}$ \\
\hline
\end{tabular}

Forrás: Nyíregyháza Életminösége, 2018

2. táblázat. Dolgozik-e jelenleg? $(\mathrm{N}=478)$

A városi gazdasági aktivitási jellemzők még inkább értékelendők, ha figyelembe vesszük azt, hogy a „Jelenleg nem dolgozom” kategória választását az érintettek jelentős hányada személyes okokkal magyarázta. Ezen belül a legtöbbek által megjelölt kategória a „tanulmányok folytatása” és a „nyugdíjas vagyok” kategória volt. A nem dolgozók 12,4\%-a munkával kapcsolatos okokkal, míg 83,7\% személyes okokkal magyarázta a munkától való távolmaradását. (2. táblázat)

\begin{tabular}{|c|c|c|c|}
\hline Munkával kapcsolatos okok & fö & Személyes okok & fö \\
\hline Elbocsájtottak & 6 & $\begin{array}{c}\text { GYED/GYES/GYET (van munkahe- } \\
\text { lye) }\end{array}$ & 8 \\
\hline Lejárt a szerződésem & 14 & $\begin{array}{c}\text { GYED/GYES/GYET (nincs munka- } \\
\text { helye) }\end{array}$ & 3 \\
\hline Tönkrement a vállalkozásom & 3 & Beteg, fogyatékos személy ápolása & 3 \\
\hline- & - & Költözés & 4 \\
\hline- & - & Tanulmányok folytatása & 24 \\
\hline- & - & $\begin{array}{c}\text { Saját betegség, fogyatékosság, } \\
\text { rokkantság }\end{array}$ & 11 \\
\hline- & - & Nyugdíj & 87 \\
\hline- & - & Egyéb & 23 \\
\hline
\end{tabular}

Forrás: Nyíregyháza Életminősége, 2018

3. táblázat. Jelenleg nem dolgozom választ megjelölők száma (fö) $(\mathrm{N}=186)$.

Nemenkénti megoszlást vizsgálva azt tapasztaljuk, hogy a férfiak 71,6\%-a (2015ben 66\%-a), míg a nők 55,6\%-a (2015-ben 47\%-a) rendelkezett rendszeres jövedelmet biztosító állással. (3. táblázat)

A válaszadók meghatározó része (45,6\%) alkalmazottként szellemi tevékenységet folytató volt 2018-ben. (2. ábra) 


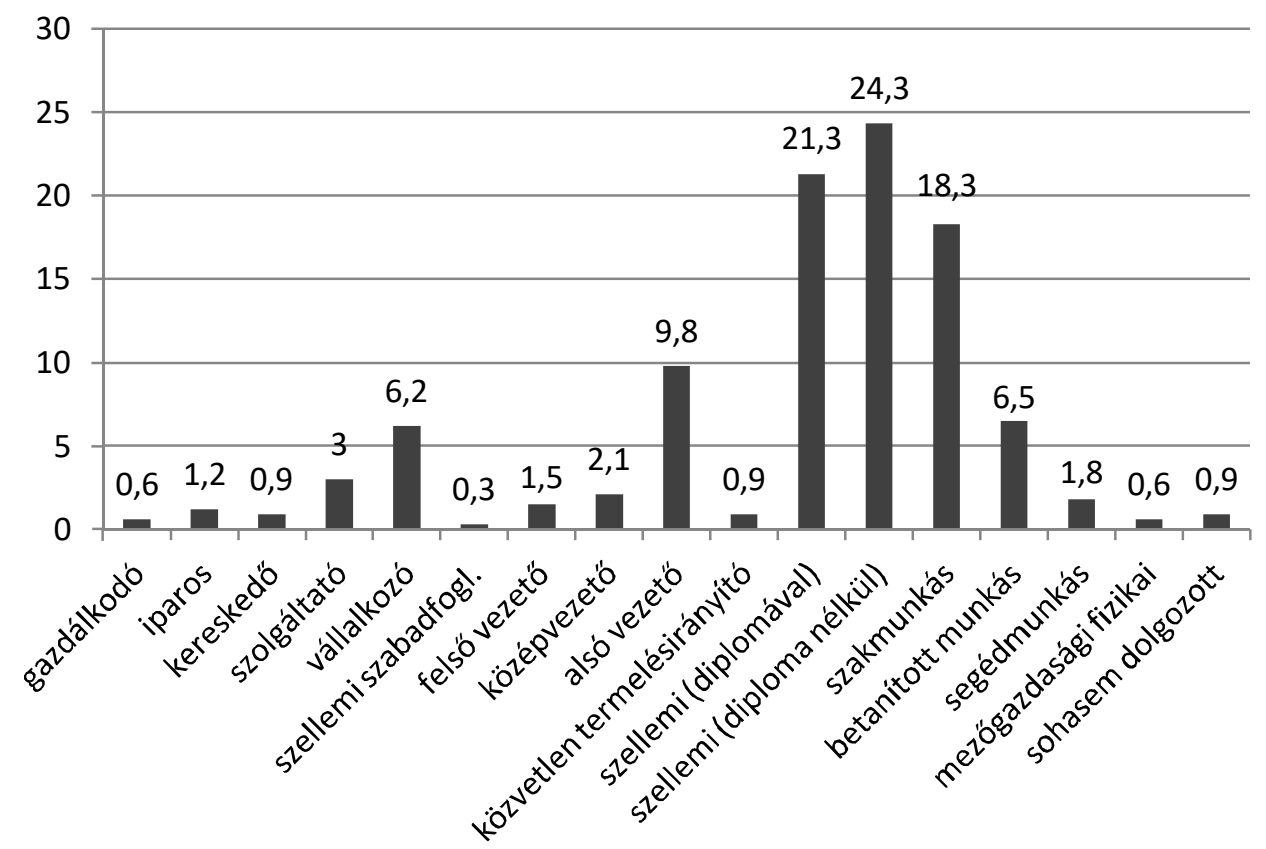

Forrás: Nyíregyháza Életminősége, 2018

2. ábra. Az alábbi kategóriák közül válassza ki azt, amely jellemző Önre!

A legnagyobb csoportot a heti 40 órában foglalkoztatottak alkotják (76,3\%) 48 és 60 óra közötti heti munkaóráról a megkérdezettek 15,1\%-vallott. Majd ezt követi a 6 (3,7\%) és 4 órában dolgozók aránya (3,4\%). Összességében a válaszadók 5,5\%-a dolgozik részmunkaidőben, alkalmi munkát 2,3\%-uk végez. Közfoglalkoztatottként a válaszadás időpontjában a megkérdezettek 1,9\%-a dolgozott. (4. táblázat)

\begin{tabular}{|l|c|}
\hline $\begin{array}{l}\text { Folyamatos, normál foglalkoztatás (napi } 8 \\
\text { óra, heti } 40 \text { óra, kinevezéssel) }\end{array}$ & 76,3 \\
\hline Meghatározott időre szóló szerződéssel & 8,1 \\
\hline Részmunkaidőben & 5,5 \\
\hline Közmunka program keretében & 1,9 \\
\hline Alkalmi munka, szerződés nélkül & 2,3 \\
\hline Egyéb & 5,8 \\
\hline
\end{tabular}

Forrás: Nyíregyháza Életminösége, 2018

4. táblázat. Milyen módon foglalkoztatják Önt? (\%)

Figyelemre méltó, hogy a foglalkoztatottak 43,6\%-a (151 fö) a kevésbé kiszámítható, határozott idejü szerződéssel lett alkalmazva. Ezen belül a válaszadók valamivel több, mint 40\%-nak maximum egyéves időtartamra szólt a szerződése. (5. táblázat) 


\begin{tabular}{|c|c|}
\hline Idötartam & Megoszlás (\%) \\
\hline kevesebb, mint 6 hónapra & 12,6 \\
\hline 6 hónap-1 év közötti időre & 12,6 \\
\hline 1 évre & 15,2 \\
\hline 1-2 év között & 6,6 \\
\hline 2-5 év között & 19,2 \\
\hline 5 évnél hosszabb & 33,8 \\
\hline Összesen & $\mathbf{1 0 0 , 0}$ \\
\hline
\end{tabular}

Forrás: Nyíregyháza Életminösége, 2018

5. táblázat. Amennyiben Ön szerződéssel dolgozik, kérjük, nevezze meg, milyen időtartamra kötöttek Önnel szerződést! (N=151)

Arra is kíváncsiak voltunk, hogy a munkavállalók milyen információs csatornán keresztül jutottak a jelenlegi állásukhoz. A legtöbben hirdetésen keresztül váltak alkalmazottá (30,0\%). A második legtöbbek által megjelölt válasz a család és barátok által nyújtott informális információáramlás volt (29,5\%). Közvetlenül a munkáltatóhoz fordult a válaszadók több mint egynegyede. Saját vállalkozásba 7,7\% kezdett, míg a válaszadók 6,3\%-a a munkaügyi központ általi kiközvetítés valamint közfoglalkoztatás segítségével végez jelenleg fizetett munkát. (6. táblázat)

\begin{tabular}{|c|c|}
\hline Közvetlen a munkáltatóhoz fordult & 26,6 \\
\hline Hirdetésre jelentkezett & 30,0 \\
\hline Családtól, baráttól érkezett az információ & 29,5 \\
\hline Saját vállalkozásban & 7,7 \\
\hline Kiközvetítés, közmunka & 6,3 \\
\hline
\end{tabular}

Forrás: Nyíregyháza Életminösége 2018

6. táblázat. Hogyan jutott ehhez az álláshoz, milyen információkkal rendelkezett? (\%) $(\mathrm{N}=309)$

A válaszadók meghatározó része több munkahelyen dolgozott eddigi élete során. Mindössze 11,6\%-uk válaszolta azt, hogy eddig egy munkahelye volt. A legtöbbek által megjelölt kategória a két munkahely volt $(33,6 \%)$, de jelentősnek tekinthető a három $(19,8 \%)$, négy $(10,4 \%)$, öt $(8,8 \%)$ munkahellyel rendelkezők aránya is. Figyelemre méltó, hogy a megkérdezettek közel 10\%-a kilenc vagy annál több munkahelyet tud maga mögött.

A munkahelyek száma és az iskolai végzettség között statisztikailag releváns öszszefüggést találtunk $(\mathrm{p}=0,006)$. A kereszttábla elemzés alapján megállapítottuk, hogy az alacsonyabb iskolai végzettség többszöri munkahelyváltásra determinál a gazdaságilag aktív életszakaszban. Nemek tekintetében az tapasztaltuk, hogy a férfiak több munkahelyen dolgoztak eddig, mint a nők.

A város lakóinak közel fele $(49,4 \%)$ volt már regisztrált munkanélküli eddigi élete során. A munkanélküliség időtartama szerinti megoszlás szerint az tapasztaltuk, hogy a többség fél és egy év közötti időszakot töltött munkanélküliként. A válaszadók átlagosan 10 hónapot töltöttek el munka nélkül. Viszonylag kevesen, 6,7\% (31 fö) vett már rész közmunkaprogramban. 11 fö $(2,4 \%)$ jelenleg is ilyen keretek 
között dolgozik. A legtöbben (14 fö) egy alkalommal vettek részt közmunkaprogramban. A második legtöbbek által megjelölt kategória a három volt ( 8 fó), a harmadig pedig a négy alkalom (3 fö). A közfoglalkoztatásban eltöltött átlagos időtartam 16,6 hónap volt. Ebben az időszakban irodai, ügyintézői, karbantartási, takarítási gondnoki, takarítási, gondnoki, pedagógiai asszisztensi, gyermekgondozási, portaszolgálati feladatokat láttak el az érintettek, de voltak, akik segédmunkát, festés-mázoltást végeztek.

\begin{tabular}{|c|c|}
\hline Volt-e regisztrált munkanélküli eddigi élete során? N=465 & Megoszlás (\%) \\
\hline igen & 18,3 \\
\hline igen, de jelenleg nem az & 31,1 \\
\hline nem & 50,6 \\
\hline
\end{tabular}

\begin{tabular}{|c|c|}
\hline Vett-e már részt közmunka programban? $\mathbf{N = 4 6 7}$ & Megoszlás (\%) \\
\hline igen, jelenleg is abban dolgozik & 2,4 \\
\hline igen, de jelenleg nem abban dolgozik & 4,3 \\
\hline nem & 93,3 \\
\hline
\end{tabular}

Forrás: Nyíregyháza Életminösége, 2018

7. táblázat. Munkanélküliséggel, közmunkával kapcsolatos információk.

Arra is kíváncsiak voltunk, hogy a közmunka programban való részvétel hogyan befolyásolta a válaszadók életkörülményeit. Ezért arra kértük a válaszadókat, hogy egy 5 fokú skálán az iskolai osztályzatoknak megfelelően értékeljék, hogy a közfoglalkoztatás során mennyire javultak az életkörülményeit. A vélemények szinte 50-50\%-ban oszlottak meg az egyáltalán nem javultak/mérsékelten javultak és a javultak is meg nem is/nagyobb mértékben javultak kategóriákban. 4 fó válaszolta azt, teljes mértékben javultak az életkörülményei. (7. táblázat)

A megkérdezettek közel 10\%-a végez a föállása mellett egyéb jövedelemszerző tevékenységet. Közel ennyien (12,2\%) szoktak önkéntes munkát vállalni. A másodállás és az iskolai végzettség, valamint a nem változók között nem találtunk szignifikáns összefüggést.

Mint már említettük az ember életének fontos, kitüntetett területe a munka világa. A munkavégzés kedvező hatással bír az élet minden területén, abban az esetben, ha az egyén olyan munkát végezhet, amivel szívesen foglalkozik, valamint ha a megszerzett képzettség és a ténylegesen ellátott munka jól illeszkedik egymáshoz. Azonban a modern társadalmakban az emberek többségének munkavégzésére nem ez a jellemző. „Gyakori, hogy az ember nem saját döntésével választotta a munkáját, hanem a megélhetés miatt belekényszerült abba. A munka, amit végez, így nem az övé, elégedetlenséget, feszültséget él meg." (Bánlaky 2001:115). Ezen túl a képzettség és a ténylegesen ellátott munka illeszkedési deficitje további frusztrációt eredményezhet az egyén szintjén, össztársadalmi szinten pedig a munkaerőforrással való gazdálkodás pazarlásaként foghatjuk fel ezt a jelenséget. A munkavégzéssel kapcsolatos nehézségek, az ezzel összefüggő feszültségteli általános közérzet egészségromláshoz, vagy akár családon belüli konfliktushoz is vezethet.

A nyíregyházi városlakók 36,7\%-a nyilatkozott úgy, hogy lelkileg megterhelő, stresszes munkát végez. Közel ugyanennyien gondolják úgy, hogy néha előfordul, 
hogy lelkileg megterhelö, stresszes a munkájuk. 27,8\% soha, vagy szinte soha nem tapasztal ilyen jellegü nehézséget munkájával kapcsolatban. (3. ábra)

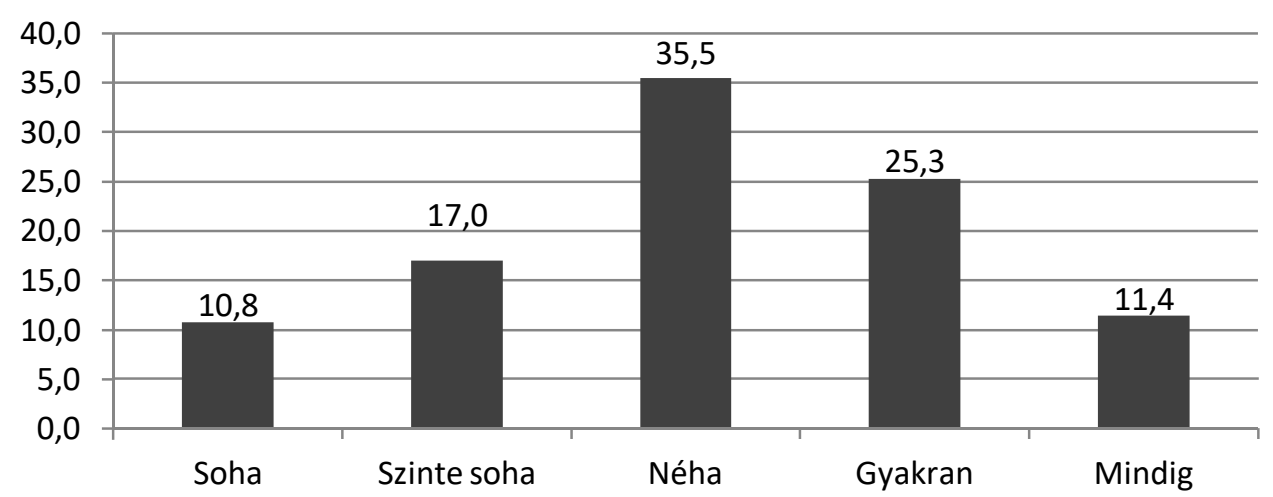

Forrás: Nyíregyháza Életminősége, 2018

3. ábra. Lelkileg megterhelö, stresszes a munkája?

Megvizsgáltuk, vajon a nőkre vagy a férfiakra, a fiatalabb, vagy idősebb generációra, a kvalifikáltabb, vagy kevésbé iskolázott válaszadókra érvényes-e inkább a munkavégzésből eredő lelki leterheltség. A nem változó nem mutatott szignifikáns összefüggést ebböl a szempontból, viszont az életkor $(\mathrm{p}=0,022)$ és iskolai végzettség $(\mathrm{p}=0,000)$ milyensége meghatározó voltáról árulkodik a lefuttatott statisztikai próba. (8. és 9. táblázat)

Az életkori csoportok tekintetében a soha kategóriát megjelölők alacsony aránya mellett az is megfigyelhetö, hogy leginkább a 60+-os korosztály mentesül a munka által okozta stresszhelyzettől. Ez vélhetően a nyugdíjkorhatár elérésével és az ezzel összefüggő, mnkaerőpiacról való kivonulással magyarázható. A néha válaszkategória megoszlása azt mutatja, hogy általában minden korosztály megtapasztalja, a munkafeszültség érzését, még ha csak alkalmanként is. Ami viszont a legfontosabb eredménye a mért összefüggésnek az az, hogy a munkavégzéssel összefüggő gyakori, vagy állandósult stresszhelyzet a 40-49 éves korosztályt érinti a leginkább. Mindemellett gyakorta jelentkező feszültséggel küzd az 50-59 évesek 27,4\%-a.

\begin{tabular}{|c|c|c|c|c|c|c|}
\hline $\begin{array}{c}\text { Lelkileg megterhelö (stresszes) a } \\
\text { munkája }\end{array}$ & \multicolumn{7}{|c|}{ Életkori csoport } \\
& $20-$ & $30-$ & $\mathbf{4 0 -}$ & $50-$ & $60+$ & Összesen \\
\hline Soha & 29 & 39 & $\mathbf{4 9}$ & 59 & & \\
\hline Szinte soha & 8,2 & 11,8 & 6,1 & 9,6 & 25,6 & 11,1 \\
\hline Néha & 14,8 & 20,4 & 9,1 & 26,0 & 17,9 & 18,1 \\
\hline Gyakran & 42,6 & 31,2 & 33,3 & 32,9 & 30,8 & 34,0 \\
\hline Mindig & 23,0 & 24,7 & $\mathbf{3 0 , 3}$ & 27,4 & 12,8 & 24,7 \\
\hline & 11,5 & 11,8 & $\mathbf{2 1 , 2}$ & 4,1 & 12,8 & 12,0 \\
\hline
\end{tabular}

$\mathrm{p}=0,022$

Forrás: Nyíregyháza Életminösége, 2018

8. táblázat. „Lelkileg megterhelő, stresszes a munkája" megoszlása az életkori csoportok függvényében $(\mathrm{N}=332)$. 


\begin{tabular}{|c|c|c|c|c|c|}
\hline $\begin{array}{c}\text { Lelkileg megterhelö } \\
\text { (stresszes) a munkája }\end{array}$ & \multicolumn{5}{|c|}{ Iskolai végzettség } \\
\hline & 8 általános & $\begin{array}{c}\text { Szakiskola } \\
\text { érettségi } \\
\text { nélkül }\end{array}$ & Érettségi & Felsőfok & Összesen \\
\hline Soha & 22,6 & 15,3 & 12,5 & 5,0 & 11,7 \\
\hline Szinte soha & 38,7 & 22,2 & 19,2 & 10,9 & 19,1 \\
\hline Néha & 22,6 & 33,3 & 33,3 & 38,6 & 34,0 \\
\hline Gyakran & 12,9 & 11,1 & $\mathbf{3 0 , 0}$ & $\mathbf{2 8 , 7}$ & 23,8 \\
\hline Mindig & 3,2 & $\mathbf{1 8 , 1}$ & 5,0 & $\mathbf{1 6 , 8}$ & 11,4 \\
\hline
\end{tabular}

$\mathrm{p}=0,000$

Forrás: Nyíregyháza Életminősége, 2018

9. táblázat. „Lelkileg megterhelő, stresszes a munkája” megoszlása az iskolai végzettség függvényében $(\mathrm{N}=332)$.

Az iskolai végzettség és a munka által okozott stresszhelyzet elemzésénél igen összetett kép tárult elénk. A „soha” és „szinte soha” lehetőséget megjelölők jelentős hányada a legfeljebb 8 általános iskolai osztállyal, valamint a szakiskolai végzettséggel rendelkezők köréből került ki. Ezzel szemben gyakori stresszhelyzet éri az érettségizett és diplomás munkavállalókat. Az állandó feszültségteli munkavégzés leginkább a szakiskolai valamint a felsőfokú végzettséggel rendelkezőket érinti.

A válaszadók leterheltsége, kimerültsége érthető tetten a 4. ábra adataiból. Azok aránya, akik úgy nyilatkoztak, hogy gyakran, illetve a mindig leterheltnek érzik magukat meghaladja a válaszadók $60 \%$-át. Néha jelentkező kimerültségről a válaszadók közel egyharmada vallott, kevésbé, vagy sohasem érzi kimerültnek magát a városlakók 6,6\%-a. (4. ábra)

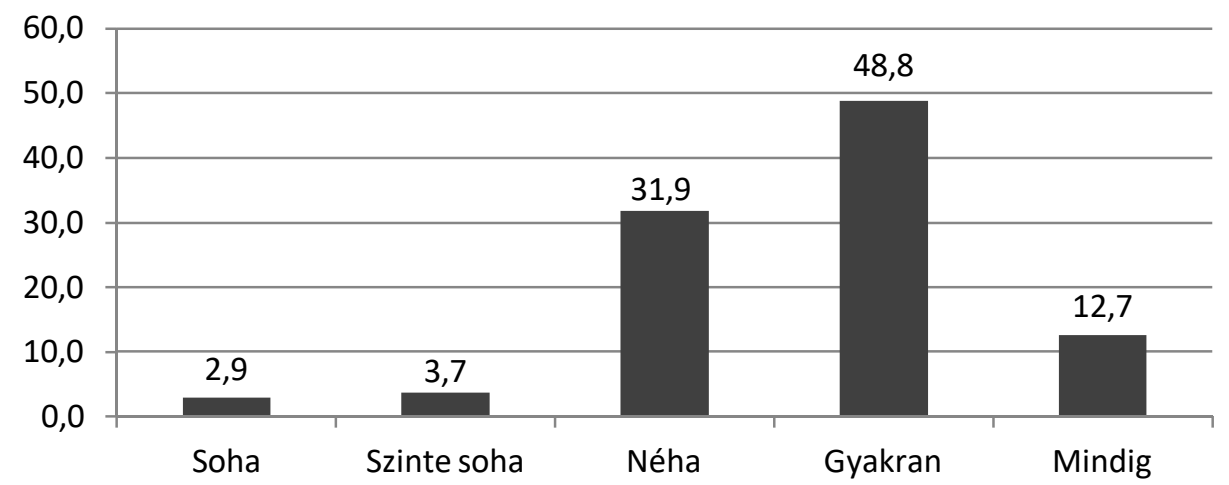

Forrás: Nyíregyháza Életminősége, 2018

4. ábra. Kimerülten érkezik haza? $(\mathrm{N}=350)$

A munkavégzéssel kapcsolatos kimerültség érzése nem mutatott szignifikáns összefüggést a nem (férfi/nő) változóval $(p=0,220)$. Ez azt jelenti, hogy nem jellemzőbb egyik nemre sem, hogy kimerültebben érkezne haza a munkából, mint a másik. Vagyis a nők és férfik munkával összefüggő kimerültsége nem tér el. Ez vélhetően a 
kétkeresős családmodell működésének általános jellemzője. Az életkor és az iskolai végzettség változó azonban összefüggést jelzett.

\begin{tabular}{|c|c|c|c|c|c|c|}
\hline $\begin{array}{c}\text { Kimerültten érkezik haza a } \\
\text { munkából? }\end{array}$ & \multicolumn{7}{|c|}{ Életkori csoport } \\
& $\begin{array}{c}20- \\
29\end{array}$ & $\begin{array}{c}30- \\
39\end{array}$ & $\begin{array}{c}\mathbf{4 0 -} \\
\mathbf{4 9}\end{array}$ & $\begin{array}{c}50- \\
59\end{array}$ & $60+$ & Összesen \\
\hline Soha & 0,0 & 2,1 & 3,0 & 2,7 & 12,2 & 3,3 \\
\hline Szinte soha & 5,0 & 3,2 & 6,0 & 2,7 & 2,4 & 3,9 \\
\hline Néha & 28,3 & 25,5 & 29,9 & 45,9 & 24,4 & 31,3 \\
\hline Gyakran & $\mathbf{5 0 , 0}$ & $\mathbf{6 0 , 6}$ & $\mathbf{4 0 , 3}$ & $\mathbf{4 4 , 6}$ & $\mathbf{3 6 , 6}$ & $\mathbf{4 8 , 2}$ \\
\hline Mindig & 16,7 & 8,5 & $\mathbf{2 0 , 9}$ & 4,1 & 24,4 & 13,4 \\
\hline
\end{tabular}

$\mathrm{p}=0,001$

Forrás: Nyíregyháza Életminősége, 2018

10. táblázat. „Kimerülten érkezik haza” ” megoszlása az életkori csoportok függvényében $(\mathrm{N}=336)$ ?

A 10. táblázat adataiból látható, hogy a 20-29 éves korosztály több mint háromnegyede gyakran, illetve mindig kimerülten érkezik haza. Valamivel kisebb arányban, de hasonlóan nyilatkozott a 30-39 éves korcsoport, majd a 40-49 éves korcsoport érintettsége következik a sorban. Az is megfigyelhetö, hogy az állandósult kimerültség a 60+-os korcsoportra illetve a 40-49 évesekre jellemző. Előbbi csoport véleménynyilvánítását vélhetően az életkori hatás is alakította.

\begin{tabular}{|c|r|r|r|r|r|}
\hline $\begin{array}{c}\text { Kimerülten } \\
\text { érkezik haza a } \\
\text { munkából? }\end{array}$ & \multicolumn{5}{|c|}{ Iskolai végzettség } \\
\hline & 8 általános & $\begin{array}{c}\text { Szakiskola } \\
\text { érettségi } \\
\text { nélkül }\end{array}$ & Érettségi & Felsőfok & Összesen \\
\hline Soha & 6,1 & 5,6 & 1,7 & 2,0 & 3,1 \\
\hline Szinte soha & 0,0 & 0,0 & 5,0 & 6,0 & 3,7 \\
\hline Néha & 15,2 & 29,6 & 35,8 & 38,0 & 33,0 \\
\hline Gyakran & $\mathbf{6 3 , 6}$ & 45,1 & 46,7 & 48,0 & 48,5 \\
\hline Mindig & 15,2 & $\mathbf{1 9 , 7}$ & 10,8 & 6,0 & 11,7 \\
\hline
\end{tabular}

$\mathrm{p}=0,029$

Forrás: Nyíregyháza Életminősége, 2018

11. táblázat. „Kimerülten érkezik haza” ” megoszlása az iskolai végzettség függvényében $(\mathrm{N}=324)$.

Az iskolai végzettség statisztikailag relevánsan összefügg a kimerültség érzésével. (11. táblázat) A 8 általánossal sem rendelkezők nyilatkoztak a legnagyobb arányban $(63,6 \%)$ arról, hogy gyakran előfordul, hogy kimerülten érkeznek haza a munkából. A többi iskolai végzettség szerinti csoport ebből a szempontból hasonlóan nyilvánult meg. Körükben 45,1-48\% között van a gyakori kimerültségre panaszkodók aránya. A folyamatos kimerültség a szakiskolai végzettséggel és legfeljebb nyolc általános iskolai osztállyal rendelkezőket érinti a leginkább. Elöbbiek körében minden ötödik, utóbbiak esetében minden hatodik válaszadóra jellemző a munkavégzést követő állandó 
kimerültség. Megállapítható tehát, hogy az alacsonyabban kvalifikált társadalmi csoportokra inkább jellemző a munkavégzésből adódó kimerültség. A közép és felsőfokú végzettségüek érintettsége kevésbé jelentős. A megállapított összefüggés azzal magyarázható, hogy az alacsonyabb iskolai végzettségüek időben több, a munka milyenségét tekintve pedig fizikailag megterhelőbb munkát végeznek $(\mathrm{p}=0,000)$. A legfeljebb 8 osztállyal rendelkezők és a szakiskolát végzettek közül minden ötödik illetve hatodik válaszadó végez minden napos gyakorisággal nehéz fizikai munkát. Ez a középfokú és felsőfokú végzettséggel bírók esetében mindössze 5,8 és 2,0\%. A legmagasabb iskolai végzettségü csoport 45,5\%-a, a középfokú végzettségüek több, mint egynegyede soha nem végez fizikai munkát, szemben a legfeljebb 8 általánossal (11,8\%) és a szakiskolai végzettséggel rendelkező (11,0\%) munkavállalókkal.

A gazdasági aktivitás kérdéskörén belül a következőkben a munkával, munkavégzés körülményeivel való elégedettségre kérdeztünk rá, függetlenül attól, hogy közmunka programban dolgoznak-e az érintettek vagy sem.

\begin{tabular}{|c|c|}
\hline egyáltalán nem elégedett & 11,2 \\
\hline nem elégedett & 15,0 \\
\hline elégedett is és nem is & 30,0 \\
\hline elégedett & 31,3 \\
\hline teljes mértékben elégedett & 12,5 \\
\hline
\end{tabular}

Forrás: Nyíregyháza Életminösége. 2018

12. táblázat. Mennyire elégedett Ön jelenlegi fizetésével, jövedelemével? (\%) N=373

A város válaszadói közül közel ugyanannyian „,elégedettek” (31,3\%) és ,,elégedettek is meg nem is" (30\%) a fizetésükkel és közel annyian jelölték meg a "teljesen elégedett” (12,5\%) mint az ,egyáltalán nem elégedett” (11,2\%) kategóriát. Az inkább elégedettek csoportjába tartoznak a 20-29 évesek, a 30-39 évesek valamint a 40-49 évesek. Az elégedetlenebbek csoportját az 50-59 valamint a 60+-os korosztály erösíti ( $\mathrm{p}=0,001)$. Az iskolai végzettség szintén fontos szerepet játszik a fizetéssel kapcsolatos véleménynyilvánításban. A legfeljebb 8 általános iskolával rendelkezők körében a legmagasabb az elégedetlenek aránya, mely meghaladja az 50\%-ot. Körükben a semleges ,,elégedett is vagyok meg nem is ” válasz 25,6\%-ukra érvényes az ,elégedett” illetve „teljes mértékben elégedett” 23,1\%-ukra. Az elégedettség ranglétráján egy lépcsőfokkal feljebb helyezkedik el a szakiskolával és érettségivel rendelkezők csoportja. Ettől határozottan elkülönülnek a felsőfokú végzettségüek, 63,7\%-uk inkább elégedett illetve teljes mértékben elégedett a jövedelmével $(\mathbf{p}=\mathbf{0 , 0 0 0})$. (12. táblázat)

\begin{tabular}{|c|c|}
\hline egyáltalán nem elégedett & 3,9 \\
\hline nem elégedett & 9,0 \\
\hline elégedett is és nem is & 27,0 \\
\hline elégedett & 39,1 \\
\hline teljes mértékben elégedett & 21,1 \\
\hline
\end{tabular}

Forrás: Nyíregyháza Életminősége, 2018

13. táblázat. Mennyire elégedett Ön a munkavégzés körülményeivel? (\%) N=354 
A munkavégzés körülményeiről alkotott vélemények egy inkább elégedett helyi társadalom képét festi elénk. 60,2\%-uk tarozik az „elégedettek” és a „teljes mértékben elégedettek" táborába. A feltüntetett válaszlehetőségek közül az elégedett verziót választották a legtöbben (39,1\%). (13. táblázat) Közel egyharmaduk az ,elégedett is és nem is" semleges válaszlehetőséget jelölte meg. Egyértelmü elégedetlenségéről vallott a válaszadók 12,9\%-a. (13. táblázat)

Összefüggést találtunk a munkavégzés körülményeivel való elégedettség és a $\mathrm{Z}$ életkor között ( $\mathrm{p}=0,000)$. Azt tapasztaltuk, hogy a teljes mértékben elégedettek a 2029, 30-39 éves valamint a 60+-os korosztályhoz tartoznak. Ebből a szempontból az 50-59 évesek és 40-49 évesek kedvezőtlenebbül nyilatkoztak. A munkavégzés körülményeiröl vallott vélemények szignifikáns kapcsolatot jeleznek az iskolai végzettség változóval is $(\mathrm{p}=0,000)$. A felsőfokú végzettséggel bírók a legelégedettebbek, háromnegyedük tartozik az elégedettek és teljes mértékben elégedettek csoportjához. Öket követik a szakiskolai végzettséggel bírók (61\%) és kicsit lemaradva következik az érettségizettek csoportja (58,2\%). Élesen elkülönülnek a legfeljebb 8 általános iskolával bírók ebből a szempontból. Körükben 31,3\%-os az elégedettségi arány és ennél magasabb 35,7\%-os az elégedetlenek és teljes mértékben elégedetlenek aránya. Ez utóbbi kategóriába a szakiskolával rendelkezők 14,6\%, az érettségizettek 8,7\%-a , a felsőfokú végzettséggel rendelkezők 5\%-a tartozik.

A munkaidő beosztáshoz és a munka típusához kötődő elégedettség mértéke is kiemelkedőnek tekinthető. Közel 70\%-os elégedettségi ráta mutatkozott mindkét kérdés esetén.

\begin{tabular}{|c|c|}
\hline egyáltalán nem elégedett & 2,5 \\
\hline nem elégedett & 9,2 \\
\hline elégedett is és nem is & 21,2 \\
\hline elégedett & 37,8 \\
\hline teljes mértékben elégedett & 29,3 \\
\hline
\end{tabular}

Forrás: Nyíregyháza Életminősége, 2018

14. táblázat. Mennyire elégedett Ön a munkaidő beosztásával? (\%) N=353

Kíváncsiak voltunk arra, hogy a munkaidő beosztással kapcsolatos elégedettség függ-e a nem (férfi-nő), az életkor és az iskolai végzettség változóktól. Eredményeink mindhárom esetben meghatározó összefüggést mutattak $(\mathrm{p}=0,001$; $\mathrm{p}=0,002 ; \mathrm{p}=0,000)$. A kereszttábla vonatkozó adatai alapján a következő megállapítást tettük: a férfiak kevésbé elégedettek ebből a szempontból, mint a nők. Életkor szempontjából a 20-29 valamint a 40-49 évesek elégedetlensége rajzolódik ki. Iskolai végzettség szempontjából pedig a legfeljebb 8 osztállyal rendelkezők a legelégedetlenebbek és a felsőfokú végzettségúek a legelégedettebbek, ahogyan azt a munkavégzés körülményeinél is tapasztaltuk. (14. táblázat)

A munka típusánál az életkor $(\mathrm{p}=0,012)$ és az iskolai végzettség $(\mathrm{p}=0,000)$ jelzett szignifikáns kapcsolatot. A fiatalok (20-29 évesek) valamint a felsőfokú végzettségűek elégedettsége a leginkább meghatározó. (15. táblázat) 


\begin{tabular}{|c|c|}
\hline egyáltalán nem elégedett & 3,9 \\
\hline nem elégedett & 6,3 \\
\hline elégedett is és nem is & 20,4 \\
\hline elégedett & 36,1 \\
\hline teljes mértékben elégedett & 33,3 \\
\hline
\end{tabular}

Forrás: Nyíregyháza Életminősége, 2018

15. táblázat. Mennyire elégedett Ön a munka típusával? (\%) N=353

A következő kérdésekre adott válaszokkal azt mértük fel, hogy a felsorolt állításokat mennyire tartják fontosnak az érintettek. Majd ehhez képest arra is rákérdeztük, hogy ezekkel a fontosnak vagy kevésbé fontosnak ítélt jellemzőkkel rendelkeznek-e? Például elsőször arra voltunk kíváncsiak, hogy menyire fontos az, hogy egy állás biztos legyen, majd afelöl érdeklődtünk, hogy a válaszadónak van-e biztos állása. (16. táblázat)

\begin{tabular}{|c|c|c|c|}
\hline \multirow{2}{*}{$\begin{array}{c}\text { Mennyire fontos Önnek, hogy egy állás } \\
\text { biztos legyen? }(\%) \mathrm{N}=453\end{array}$} & \multicolumn{2}{|c|}{$\begin{array}{c}\text { Biztos állása van } \\
(\%) \mathrm{N}=344\end{array}$} \\
\hline $\begin{array}{c}\text { egyáltalán nem } \\
\text { fontos }\end{array}$ & 0,4 & $\begin{array}{c}\text { egyáltalán nem } \\
\text { igaz }\end{array}$ & 8,6 \\
\hline nem fontos & 1,2 & nem igaz & 7,2 \\
\hline $\begin{array}{c}\text { fontos is meg } \\
\text { nem is }\end{array}$ & 4,5 & igaz is, meg nem is & 16,3 \\
\hline fontos & 34,9 & igaz & 42,2 \\
\hline nagyon fontos & 58,9 & nagyon igaz & 25,7 \\
\hline
\end{tabular}

Forrás: Nyíregyháza Életminősége, 2018

16. táblázat. A „biztos állásra” vonatkozó válaszok aránya.

Az adatokból egyértelmüen kiderül, hogy a nyíregyházi válaszadók 93,8\%-nak fontos, illetve nagyon fontos az állás biztonsága, mely a stabilitást, a kiszámítható életvitelt szavatolja az egyének, családok számára. Ezzel szemben a megkérdezés pillanatában fizetett munkát végzők mindössze 67,9\%-a mondta azt egyértelmüen, hogy jelenlegi állása biztos, vagyis nem fél az állásvesztéstől. A fennmaradó 32,1\% munkavállaló munkakörülményeit inkább a bizonytalanság jellemzi. 15,8\% válaszolta azt, hogy egyáltalán nem illetve, hogy inkább nem jellemző rá, hogy biztos állással rendelkezik. 16,3\% fejezte ki bizonytalanságát a kérdéssel kapcsolatosan.

A munka biztonsága után a magas kereseti lehetőség a legtöbbek által preferált kategória, (89,7\%) ítélte fontosnak illetve nagyon fontosnak. A munka érdekessége és az előrejutási lehetőség szintén a ragsor elejére került (75,7\% és 74,9\%). Az önálló munkavégzés fontossággát a megkérdezettek 71,5\%-a tartotta fontosnak, a végzett munka társadalmi hasznosságát közel ennyien tartották nagyra (69,2\%). 67,7\% mondta azt, hogy fontos neki, hogy olyan munkát végezzen, amellyel másoknak segíthet. Az önállóan megválasztott napszakra vonatkozó munkaidőt tartották a legkevésbé fontosnak a megkérdezettek. Ez összefüggést mutat a munkaidö beosztásával kapcsolatosan tapasztalt $70 \%$ feletti elégedettségi rátával. 
A 70\% feletti elégedettséget mutató tényezőket megvizsgáltuk a korábban alkalmazott három magyarázó változó vonatkozásában (nem, életkor, iskolai végzettség).

A nem változó szignifikáns kapcsolatot mutatott a ,jó lehetöségek legyenek az elöre jutásra” ( $\mathrm{p}=0,009)$, az ,olyan munka legyen, amellyel másoknak segithetünk” $(\mathrm{p}=0,040)$, valamint a ,olyan munka legyen, ahol az ember szabadon dönti el, hogy a nap melyik szakaszában, illetve mely napokon dolgozik" változókkal $(\mathrm{p}=0,018)$. A válaszok mintázatából kiderült, hogy a nők nagyobb arányban jelölték meg a nagyon fontos kategóriát, a „jó lehetöségek legyenek az elöre jutásra” opció vonatkozásában, mint a férfiak, viszont a férfiak közül többen választották a nagyon fontos válaszlehetőséget. A másokon való segítés fontossága a válaszlehetőségek két végpontján, a nagyon fontos és az egyáltalán nem fontos opcióknál vált el élesen. A férfiak körében többen vannak azok, akik úgy vélték, hogy ez egyáltalán nem fontos, a nők körében pedig azok, akik a nagyon fontosnak tartják munkájuk ezen jellemzőjét. A két nem közül a férfiak tartják fontosabbnak azt, hogy szabadon dönthessenek arról, hogy mely napokon és milyen napszakban dolgozzanak. Körükben 54,2\% vélekedett erről, mint fontos, vagy nagyon fontos jellemző, szemben a nőkkel, akiknél ez az arány 39,2\% volt.

Az életkor a munka érdekessége $(p=0,048)$, a másokon való segítés lehetősége $(p=0,002)$ és a munka társadalmi hasznossága $(p=0,005)$ változókkal mutatott statisztika összefüggést. A munka érdekessége a 40-49 éves korosztálynak a legfontosabb és a 20-29 éveseknek valamint a 60 felettieknek a legkevésbé fontos. A másokon való segítés megítélése szintén a 40-49 éves korosztály téma iránti érzékenységét mutatja, szemben a 20-29 és a 30-39 évesekkel. A munka társadalmi hasznosságának megítélése szintén a 40-49 évesek érintettségét mutatja az 50-59 évesek mellett.

$\mathrm{Az}$ iskolai végzettség milyensége a magas keresi lehetőség $(p=0,025)$, a munkaerőpiaci hierarchián történő előrelépéssel $(\mathrm{p}=0,000)$, a munka érdekességével $(\mathrm{p}=0,000)$ és a munkavégzés napszakának önálló megválasztásának lehetőségével mutatott kapcsolatot $(\mathrm{p}=0,000)$. A magas kereseti lehetőség a kevesebb, mint 8 osztállyal rendelkezőknek a legkevésbé fontos. A jó előrejutási lehetőséget az érettségizettek és a felsőfokú végzettségüek preferálták, szemben az ettől alacsonyabb végzettségü csoportok véleményével. A munka érdekességéröl alkotott vélemények két csoportra osztja a válaszadókat. Az egyiket a szakiskolával, érettségivel, felsőfokú végzettséggel rendelkezők alkotják, a másikat a legfeljebb általános iskolai végzettséggel rendelkezők. Utóbbi csoport tagjai értékelik a legkevésbé fontosnak azt, hogy a munka, amit végeznek érdekes legyen. Ez vélhetően összefügg ennek a csoportnak az általános munkaerőpiaci bizonytalanságával, mely a prekariátusnak mint munkaerőpiaci csoportnak általános jellemzője. (R. Fedor, Fónai, 2017). A munkavégzés napszakának önálló megválasztásának értékelése a szakiskolai végzettségüek véleményének markáns elkülönülését mutatja. Ök válaszolták a legtöbben azt, hogy ez „egyáltalán nem ” fontos vagy „,nem fontos” számukra. (17. táblázat) 


\begin{tabular}{|c|c|c|c|}
\hline & $\begin{array}{l}\text { „Fontos, } \\
\text { nagyon fon- } \\
\text { tos" }(\%)\end{array}$ & $\begin{array}{l}\text { „Fontos is } \\
\text { meg nem } \\
\text { is" }\end{array}$ & $\begin{array}{c}\text { „Egyáltalán nem } \\
\text { fontos, nem fon- } \\
\text { tos" } \\
(\%)\end{array}$ \\
\hline ...magas legyen a kereset? $\quad(\mathrm{N}=453)$ & 89,7 & 9,3 & 1,0 \\
\hline ...a munka érdekes legyen? $\quad(\mathrm{N}=452)$ & 75,7 & 18,2 & 6,0 \\
\hline $\begin{array}{c}\text {...jó lehetőségek legyenek az előrejutás- } \\
\text { ra }(\mathrm{N}=443)\end{array}$ & 74,9 & 20,7 & 4,4 \\
\hline $\begin{array}{l}\text {...önállóan végezhető munka legyen } \\
\qquad(\mathrm{N}=448)\end{array}$ & 71,5 & 20,8 & 7,8 \\
\hline $\begin{array}{c}\text {...hasznos legyen a társadalomnak? } \\
(\mathrm{N}=448)\end{array}$ & 69,2 & 21,8 & 9,1 \\
\hline $\begin{array}{c}\text {...olyan munka legyen, amellyel mások- } \\
\text { nak segíthetünk? }(\mathrm{N}=450)\end{array}$ & 67,7 & 24,7 & 7,6 \\
\hline $\begin{array}{c}\text {..olyan munka legyen, ahol az ember } \\
\text { szabadon dönti el, hogy a nap melyik } \\
\text { szakaszában, illetve mely napokon dol- } \\
\text { gozik? }(\mathrm{N}=449)\end{array}$ & 46,1 & 25,4 & 28,5 \\
\hline
\end{tabular}

Forrás: Nyíregyháza Életminösége, 2018

17. táblázat. Önnek személy szerint mennyire fontos az, hogy...

\section{Összehasonlító adatok tíz év távlatában (2008-2018)}

Az elmúlt tíz évben meghatározó gazdasági folyamatok mentek végbe nemcsak a hazai, de a globális munkaerőpiacon is. A 2008-as pénzügyi válságból kialakuló foglalkoztatási válság jelentősen átrendezte a foglalkoztatási helyzetet. Ennek hatása hazai viszonylatban 2009-2010. között csúcsosodott ki, majd az ezt követő harmadik évben már a statisztikai mutatók is azt jelezték, hogy elindult egy felfelé ívelő munkaerőpiaci tendencia.

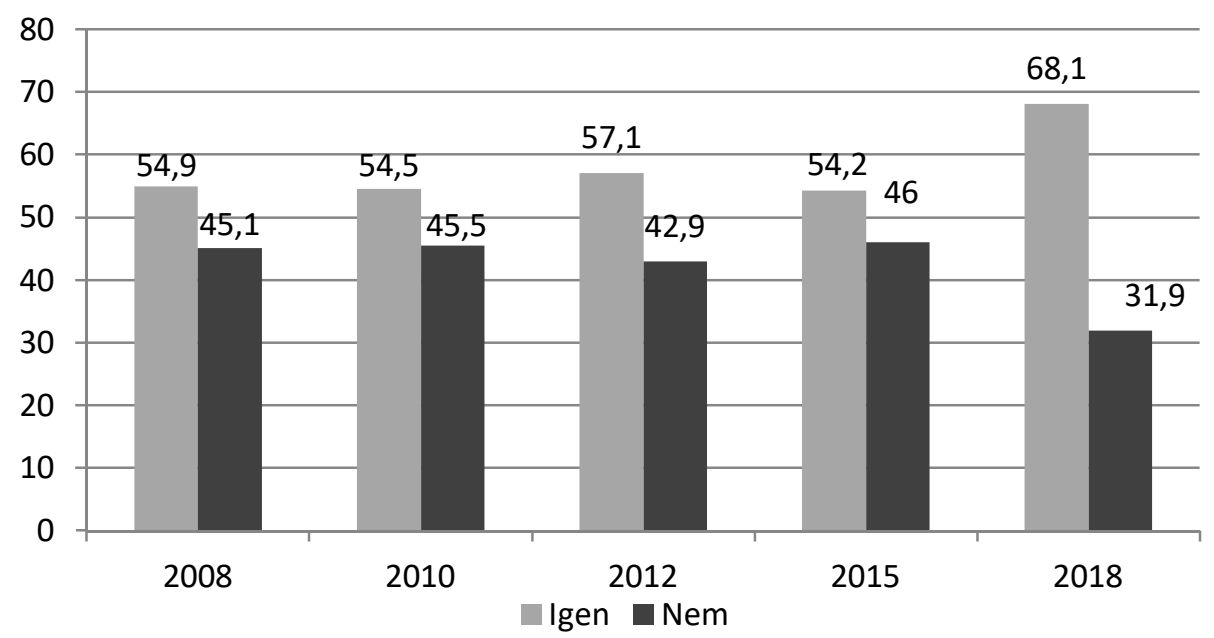

Forrás: Nyíregyháza Életminősége, 2008, 2010, 2012, 2015, 2018

5. ábra. A foglalkoztatottság aránya Nyíregyházán. 
A nyíregyházi foglalkoztatásra vonatkozó adatok ezt a tendenciát nem teljesen tükrözik vissza. Nem látszik jelentősebb visszaesés a 2008 és 2010. között, miközben a hazai foglalkoztatottak arányában jelentős apadás volt tapasztalható. Ennek az volt az oka, hogy az említett válság a kedvezőbb gazdasági és foglalkoztatási kondíciókkal rendelkező megyéket érinttette elsősorban. Így a Nyíregyházának székhelyt adó Szabolcs-Szatmár-Bereg megye érintettsége sem volt hangsúlyos. A városi adatok változatlansága továbbá a város megyeszékhely jellegéből is adódik, hiszen alapvetően itt koncentrálódik a legtöbb foglalkoztató. Ami azonban szembetünő, hogy a vizsgált tíz év vonatkozásában 13\%-kal nőtt azon válaszadók aránya, akik úgy nyilatkoztak, hogy dolgoztak a megkérdezéskor. Ez a változás egybecsen az országosan is mért tendenciával. (5. ábra)

Nemenkénti megoszlást vizsgálva azt tapasztaltuk, hogy a férfiak 71,6\%-a, míg a nők 55,6\%-a tarozott a foglalkoztatottak csoportjába 2018-ban. Az általános foglalkoztatási helyzet javulása mellett az is megfigyelhető, hogy a két nem foglalkoztatási adataiban megjelenő különbségek nem, hogy mérséklődtek volna a vizsgálati idöszakban, hanem egyre inkább karakteresebbekké váltak. A két nem közötti távolság 2008-ban 8\% volt, 2018-ban pedig 16\%. A 6. ábra adataiból az is egyértelmúen kitünik, hogy a 2008 és 2018 közötti időszakra fókuszálva a férfiak voltak a bekövetkező változások nyertesei. 2008 és 2018. között több mint 10\%-kal nőt a foglalkoztatottságuk, a nőké ennél szerényebb mértékben 2,8\%-kal.

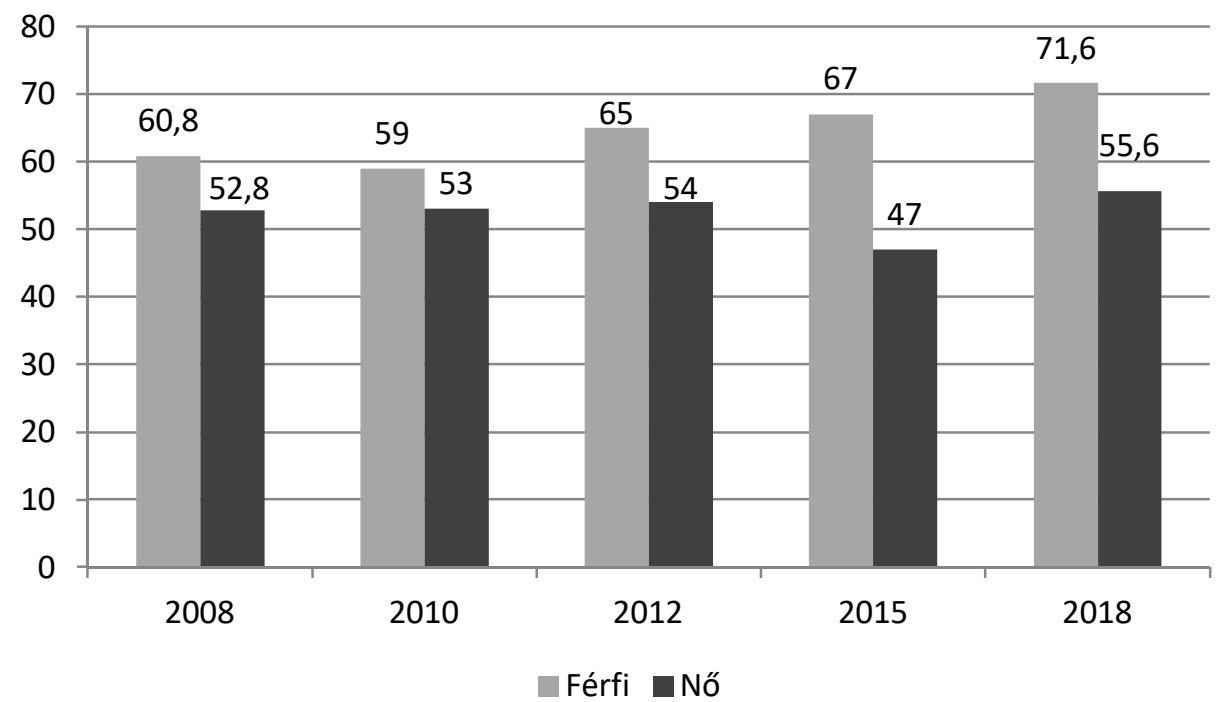

Forrás: Nyíregyháza Életminősége, 2008, 2010, 2012, 2015, 2018

6. ábra. A foglalkoztatottság aránya nemek szerint Nyíregyházán 2008, 2010, 2012, 2015, $2018(\%)$.

Az iskolai végzettség foglalkoztatásra gyakorolt pozitív hatását nem kell bizonygatni. Mind az öt lekérdezés ide vonatozó adati hüen bizonyítják, hogy a magasabb iskolai végzettség biztosabb foglalkoztatást valószínüsít. (7. ábra) Mindvégig a legfeljebb 
általános iskolai végzettséggel rendelkezők voltak a legrosszabb helyzetben az elhelyezkedés szempontjából annak ellenére, hogy a vizsgált időszakban közel 14\%-os növekedést tapasztaltunk körükben. Hasonló szintü növekedést látunk az érettségivel rendelkezőknél is és egy általános, mérsékelten javuló tendenciát a felsőfokú végzettségüek esetében. Figyelemre méltó azonban a szakiskolát, szakmunkásképzőt végzettek helyzetében bekövetkezett javulás, mely tíz év távlatában több mint 30\%-os emelkedésben öltött testet. Az elért eredményeket más szempontból is mérlegelhetjük, hiszen bizonyítottá vált, hogy a magasabb iskolai végzettségüek rendelkeznek a munkájukhoz illeszkedő, elvárt készségekkel, kompetenciákkal. Ha ez nincs meg, a munkaerőpiacon az egyén esélye lenullázódik, és hiánya akár társadalmi szegregációhoz, szegénységhez és önértékelési zavarokhoz vezethet (Láczay, 2018).

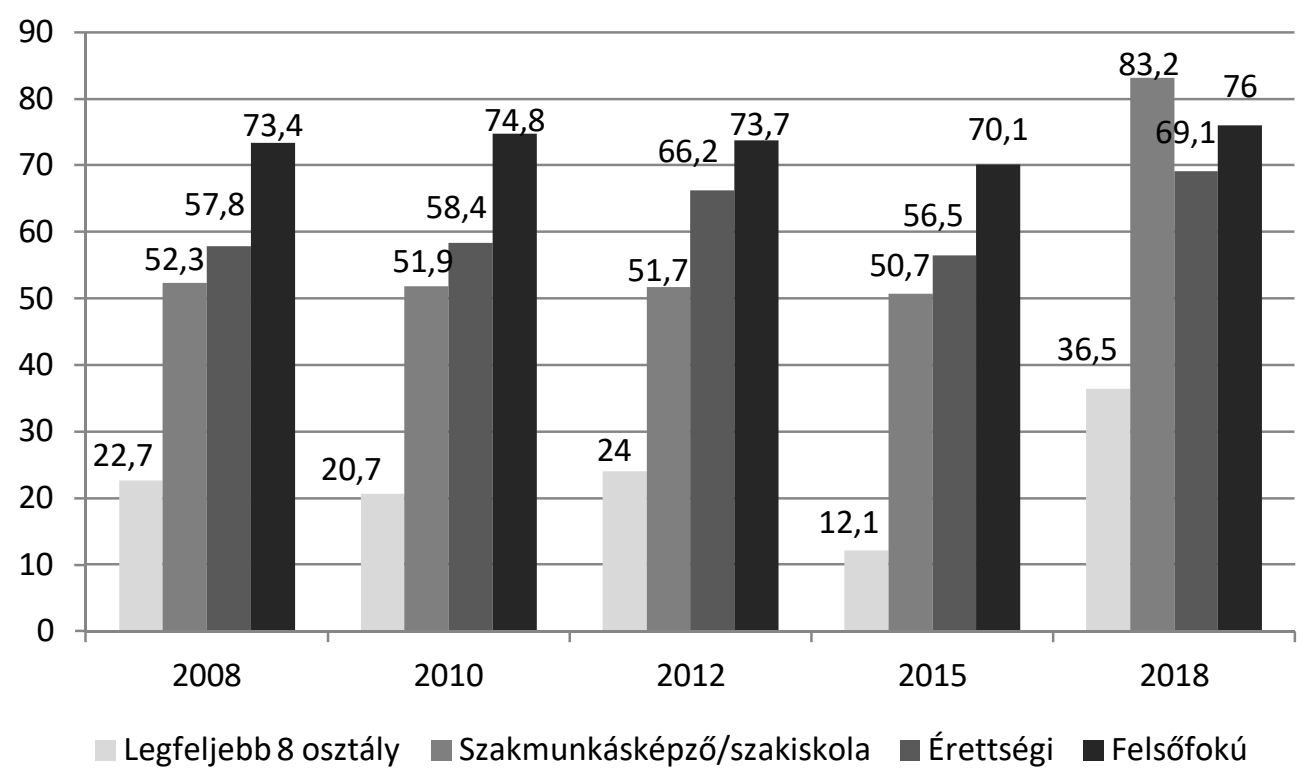

Forrás: Nyiregyháza Életminősége, 2008, 2010, 2012, 2015, 2018

7. ábra. Foglalkoztatottsági arányok az iskolai végzettség függvényében, Nyíregyházán (\%).

A legelterjedtebb foglalkoztatási forma minden vizsgált évben a normál, tipikus, napi nyolc, heti 40 órás foglalkoztatás volt. Ezt követi a meghatározott időre szóló szerződéssel dolgozók aránya. Majd a részmunkaidős valamint az alkalmi jellegü foglalkoztatás következik a rangsorban. Az önmagában kevés információtartalommal bíró, de sokat sejtető „egyéb” típusú munkavégzés hasonló arányban jellemzi a megkérdezetteket, mit a részmunkaidős foglalkoztatás. A közfoglalkoztatás keretei között viszonylag kevesen dolgoznak. Jelentősebb változás a határozott munkaidejü szerződéssel foglalkoztatottak csoportján belül tapasztalható. Míg 2012-ben minden hatodik válaszadó nyilatkozott úgy, hogy ilyen módon foglalkoztatják, addig 2018ban már csak $8,1 \%$. (18. táblázat) 


\begin{tabular}{|c|c|c|c|c|c|}
\hline & $\begin{array}{c}\mathbf{2 0 0 8} \\
(\mathbf{N = 9 2 0})\end{array}$ & $\begin{array}{c}\mathbf{2 0 1 0} \\
\mathbf{( N = 5 2 0 )}\end{array}$ & $\begin{array}{c}\mathbf{2 0 1 2} \\
(\mathbf{N = 6 4 1})\end{array}$ & $\begin{array}{c}\mathbf{2 0 1 5} \\
\mathbf{( N = 3 8 7 )}\end{array}$ & $\begin{array}{c}\mathbf{2 0 1 8} \\
\mathbf{( N = 3 2 2})\end{array}$ \\
\hline $\begin{array}{c}\text { Folyamatos, normál fog- } \\
\text { lalkoztatás (napi 8 óra, heti } \\
\text { 40 óra, kinevezéssel) }\end{array}$ & 76,6 & 78,3 & 72,2 & 74,9 & 76,3 \\
\hline $\begin{array}{c}\text { Meghatározott idóre szóló } \\
\text { szerződéssel }\end{array}$ & 10,4 & 10,8 & 15,4 & 11,4 & 8,1 \\
\hline Részmunkaidőben & 5,4 & 5,2 & 5,3 & 5,7 & 5,5 \\
\hline $\begin{array}{c}\text { Közmunka program kere- } \\
\text { tében }\end{array}$ & n.a. & n.a. & n.a. & 1,3 & 1,9 \\
\hline $\begin{array}{c}\text { Alkalmi munka, szerződés } \\
\text { nélkül }\end{array}$ & 2,0 & 1,1 & 1,6 & 1,3 & 2,3 \\
\hline Egyéb & 5,4 & 4,6 & 5,5 & 5,4 & 5,8 \\
\hline
\end{tabular}

Forrás: Nyíregyháza Életminősége, 2008, 2010, 2012, 2015, 2018

18. táblázat. Milyen módon foglalkoztatják Önt? (\%)

A közfoglalkoztatás munkaerőpiaci szerepét sokan, sokféleképpen jellemezték már. Az azonban biztos, hogy vannak olyan kistelepülések - ezek közül szeretném kiemelni az Észak-alföldi régióban található Szabolcs-Szatmár-Bereg megye egyes településeit, ahol a közmunkából származó jövedelem jelenti az egyetlen munkavégzéshez kötődő legális jövedelmet, s mint ilyen létfontosságú a családok számára. Más oldalról a közmunkához tartozó jövedelem meg sem közelíti a nyílt munkaeröpiacon müködö jövedelmeket. A nyíregyházi felmérések adatai alapján a nyíregyháziak inkább mérsékelten érintettek a közfoglalkoztatással, s jelentősebb eltérést nem is tapasztaltunk 2015 és 2018. között. (8. ábra)

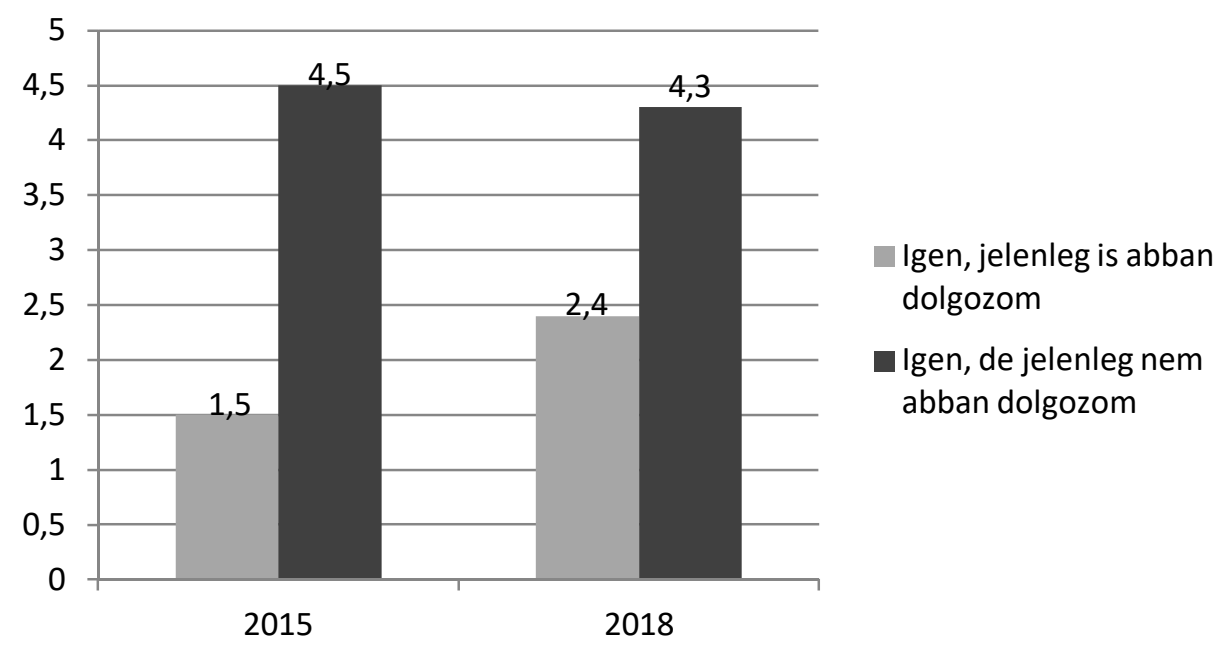

Forrás: Nyíregyháza Életminösége, 2015, 2018

8. ábra. Közfoglalkoztatásban részt vevők aránya (\%). 
Az álláskeresési stratégiák ismerete, azok alkalmazása meghatározza az érintek elhelyezkedési esélyeit. Egy adandó álláshelyről való információ segítheti, annak hiánya meghiúsíthatja az állásba kerülés sikerességét. A munkaadók munkaerő választásának módja számos esetben nem esik egybe a munkavállalók álláskeresési stratégiájával. A munkaadók először a közvetlen környezetükben a családi, baráti társaságukat majd az alkalmazásukban lévő munkavállalókat informálják egy-egy betöltetlen álláshelyről. Végső esetben fordulnak az álláshirdetés módszeréhez.

A nyíregyházi válaszadók eltérő álláskeresési módszerekről vallottak. A rangsor mind az öt vizsgálati évben szinte hasonló volt, jelentős nagyságrendbeli eltéréseket nem tapasztaltunk. Az álláskeresők közül szinte ugyanannyian találtak aktuális munkájukra úgy, hogy közvetlenül a munkaadóhoz fordultak, hirdetésre jelentkeztek illetve családtagjaik, barátaik segítségét vették igénybe. (19. táblázat)

\begin{tabular}{|c|c|c|c|c|c|}
\hline & $\begin{array}{c}\mathbf{2 0 0 8} \\
\mathbf{( N = 9 5 6 )}\end{array}$ & $\begin{array}{c}\mathbf{2 0 1 0} \\
\mathbf{( N = 5 5 9 )}\end{array}$ & $\begin{array}{c}\mathbf{2 0 1 2} \\
\mathbf{( N = 6 8 3 )}\end{array}$ & $\begin{array}{c}\mathbf{2 0 1 5} \\
\mathbf{( N = 3 8 9 )}\end{array}$ & $\begin{array}{c}\mathbf{2 0 1 8} \\
\mathbf{( N =} \\
\mathbf{3 0 9}\end{array}$ \\
\hline $\begin{array}{c}\text { Közvetlen a mun- } \\
\text { káltatóhoz fordult }\end{array}$ & 32,4 & 28,4 & 29,6 & 28,0 & 26,6 \\
\hline $\begin{array}{c}\text { Hirdetésre jelent- } \\
\text { kezett }\end{array}$ & 22,0 & 25,0 & 24,3 & 28,0 & 30,0 \\
\hline $\begin{array}{c}\text { Családtól, baráttól } \\
\text { érkezett az infó }\end{array}$ & 30,6 & 31,8 & 33,5 & 27,8 & 29,5 \\
\hline $\begin{array}{c}\text { Saját vállalkozás- } \\
\text { ban, üzletben } \\
\text { kezdte }\end{array}$ & 8,7 & 10,6 & 9,1 & 11,8 & 7,7 \\
\hline Egyéb & 6,3 & 4,1 & 3,5 & 4,4 & 6,3 \\
\hline
\end{tabular}

Forrás: Nyíregyháza Életminösége, 2008, 2010, 2018; R. Fedor, Balogh (2015), R. Fedor, Jávorné Erdei (2014) R., Fedor Anita (2012)

19. táblázat. Hogyan jutott ehhez az álláshoz? (\%)

\section{A foglalkoztatás körülményeivel kapcsolatos elégedettség}

Megvizsgáltuk, hogy változtak-e és ha igen milyen módon az egyes munkavégzéshez kapcsolódó tényezők megítélése. Korábban már bemutattuk, hogy a nyíregyházi városlakók hogyan vélekedtek 2018-ban a fizetésükről, a munkájuk típusáról, a munkavégzés körülményeiről valamint a munkaidő beosztásukról. Most pedig azt hasonlítjuk össze, hogy a véleménynyilvánítások jellege módosult-e 2008 és 2018. között. A fizetés, jövedelem megítélése az ,, egyáltalán nem elégedett” és az ,elégedetlen" kategóriákban szinte változatlan maradt. Csökkent azok aránya, akik az „,elégedett is meg nem is” válaszlehetőséggel éltek (-13\%) és közel ennyivel nőtt az elégedettek illetve teljes mértékben elégedettek aránya. Figyelemre méltó, hogy a fizetésükkel teljes mértékben elégedettek csoportját alkotók aránya nagyságrendileg megkétszereződött az elmúlt tíz évben. (20. és 21. táblázat)

A munka típusával kapcsolatos vélemények mintázata gyakorlatilag változatlan maradt. 


\begin{tabular}{|c|c|c|c|c|}
\hline & \multicolumn{2}{|c|}{$\begin{array}{c}\text { Mennyire elégedett Ön jelenlegi } \\
\text { fizetésével, jövedelemével? (\%) }\end{array}$} & \multicolumn{2}{c|}{$\begin{array}{c}\text { Mennyire elégedett Ön a } \\
\text { munka típusával? (\%) }\end{array}$} \\
\cline { 2 - 5 } & $\mathbf{2 0 0 8}(\mathbf{N}=\mathbf{9 6 2})$ & $\begin{array}{c}\mathbf{2 0 1 8} \mathbf{( N =} \\
\mathbf{3 7 3})\end{array}$ & $\begin{array}{c}\mathbf{2 0 0 8} \\
\mathbf{N}=\mathbf{9 6 6 )}\end{array}$ & $\begin{array}{c}\mathbf{2 0 1 8} \\
\text { (N= 353) }\end{array}$ \\
\hline $\begin{array}{c}\text { egyáltalán nem } \\
\text { elégedett }\end{array}$ & 10,0 & 11,2 & 1,8 & 3,9 \\
\hline nem elégedett & 15,4 & 15,0 & 4,6 & 6,3 \\
\hline $\begin{array}{c}\text { elégedett is és nem } \\
\text { is }\end{array}$ & 43,3 & 30,0 & 23,1 & 20,4 \\
\hline elégedett & 24,8 & 31,3 & 36,7 & 36,1 \\
\hline $\begin{array}{c}\text { teljes mértékben } \\
\text { elégedett }\end{array}$ & 6,4 & 12,5 & 33,7 & 33,3 \\
\hline
\end{tabular}

Forrás: Nyíregyháza Eletminösége, 2008, 2010, 2018; R. Fedor, Balogh (2015), R. Fedor, Jávorné Erdei (2014) R., Fedor Anita (2012)

20. táblázat. Munkával kapcsolatos elégedettség I. (\%).

\begin{tabular}{|c|c|c|c|c|}
\hline & \multicolumn{3}{|c|}{$\begin{array}{c}\text { Mennyire elégedett Ön a mun- } \\
\text { kavégzés körülményeivel? (\%) }\end{array}$} & \multicolumn{2}{|c|}{$\begin{array}{c}\text { Mennyire elégedett Ön a } \\
\text { munkaidő beosztásával? } \\
\text { (\%) }\end{array}$} \\
\cline { 2 - 5 } & $\mathbf{2 0 0 8}(\mathbf{N}=\mathbf{9 6 8 )}$ & $\begin{array}{c}\mathbf{2 0 1 8} \mathbf{( N )} \\
\mathbf{3 5 4})\end{array}$ & $\begin{array}{c}\mathbf{2 0 0 8} \\
\text { (N=968) }\end{array}$ & $\begin{array}{c}\mathbf{2 0 1 8} \\
\text { (N= 353) }\end{array}$ \\
\hline $\begin{array}{c}\text { egyáltalán nem } \\
\text { elégedett }\end{array}$ & 2,1 & 3,9 & 2,9 & 2,5 \\
\hline nem elégedett & 4,0 & 9,0 & 8,7 & 9,2 \\
\hline $\begin{array}{c}\text { elégedett is és } \\
\text { nem is }\end{array}$ & 25,8 & 27,0 & 21,5 & 21,2 \\
\hline elégedett & 38,2 & 39,1 & 35,0 & 37,8 \\
\hline $\begin{array}{c}\text { teljes mértékben } \\
\text { elégedett }\end{array}$ & 29,9 & 21,1 & 31,9 & 29,3 \\
\hline
\end{tabular}

Forrás: Nyíregyháza Eletminösége, 2008, 2010, 2018; R. Fedor, Balogh (2015), R. Fedor, Jávorné Erdei (2014) R., Fedor Anita (2012)

21. táblázat. Munkával kapcsolatos elégedettség II. (\%).

A munkavégzés körülményinek megítélése némileg romlott. Bár viszonylag kevesen, de 2008-hoz képest kétszer többen mondták azt, hogy egyáltalán nem elégedettek, illetve nem elégedettek a munkavégzés körülményeivel és ebből adódóan valamivel kevesebben fejezték ki elégedettségüket. Azonban egyértelműen kijelenthető, hogy az utóbbi csoportba jóval többen tartoznak mindkét vizsgálati év vonatkozásban. A munkaidő beosztásával kapcsolatos véleményekben nem mutatkozott meghatározó változás. 


\section{Összefoglalás}

Tanulmányunkban a nyíregyházi városlakók munkavállalással, foglalkoztatással kapcsolatos jellemzőit, véleményét elemeztük a Nyíregyháza Életminősége kutatássorozat keretei között. Részletesen bemutattuk a 2018-as adatbázis eredményeit, s mivel az írás alapját képező panelkutatás tíz éves múltra tekint vissza ezért lehetőségünk nyílt arra, hogy összehasonlítsuk, hogy hogyan alakult a foglalkoztatási helyzetkép 2008 és 2018. között. Eredményeik a nyíregyháziak foglalkoztatási helyzetének javulásáról árulkodnak.

2008 és 2018 között több mint 13\%-kal, 2015-höz képest közel 14\%-kal nőt azok aránya, akik úgy nyilatkoztak, hogy dolgoztak a megkérdezés idején. A válaszadók meghatározó része több munkahelyen dolgozott, $\mathrm{s}$ a város lakóinak közel fele volt már regisztrált munkanélküli eddigi élet során.

A nyíregyházi városlakók 36,7\%-a nyilatkozott úgy, hogy lelkileg megterhelő, stresszes munkát végez. A munkavégzéssel összefüggő gyakori, vagy állandósult stresszhelyzet a 40-49 éves korosztályt valamint a szakiskolai és a felsőfokú végzettséggel rendelkezőket érinti a leginkább. A válaszadók leterheltsége, kimerültsége érthető tetten a válaszokban. Gyakori illetve folyamatos leterheltségről számolt be a megkérdezettek 60\%-a. Az állandósult kimerültség a 60+-os korcsoportra illetve a 40-49 évesekre jellemző.

A megkérdezettek közel 45\%-a elégedett a fizetésével. A munkavégzés körülményeiről alkotott vélemények pedig egy még inkább elégedett helyi társadalom képét festi elénk. A munkaidő beosztáshoz és a munka típusához kötődő elégedettség mértéke is kiemelkedőnek tekinthető. Eredményeink szerint az iskolai végzettség fontos szerepet játszik a fizetéssel kapcsolatos véleménynyilvánításban. A munkaidő beosztásával kapcsolatos elégedettség szintén függ az iskolai végzettségtől, valamint a nem és az életkor változóktól.

Az „olyan munka legyen, amellyel másoknak segíthetünk” posztmateriális munkaérték inkább a nőknek és a 40-49 éves korosztály számára fontos, a „munka érdekessége" szintén a 40-49 éves korosztálynak a legfontosabb, iskolai végzettség szempontjából pedig a legalacsonyabb végzettségüek tartják a legkevésbé fontos értéknek. A férfiak a munkavégzés napjainak és napszakának szabad megválasztásban elkötelezettek.

A magas kereseti lehetőség a kevesebb, mint 8 osztállyal rendelkezőknek a legkevésbé fontos. A jó előrejutási lehetőséget az érettségizettek és a felsőfokú végzettségüek preferálták.

2008 és 2018. között 13\%-kal nőtt azon válaszadók aránya, akik úgy nyilatkoztak, hogy dolgoztak a megkérdezéskor. Az egyes iskolai végzettségi fokozatokban a szakiskolát, szakmunkásképzőt végzettek helyzetében következett be a legjelentősebb emelkedés a foglalkoztatottak arányát illetően. A legelterjedtebb foglalkoztatási forma minden vizsgált évben a normál, tipikus, napi nyolc, heti 40 órás foglalkoztatás volt. 


\section{Felhasznált irodalom}

1. Bánlaky Pál (2001): Családszociológia. Wesley János Lelkészképző Főiskola Budapest.

2. Coleman, J. S. (1996): A társadalmi tőke. In. Lengyel, Gy., Szántó, Z. (szerk). A gazdasági élet szociológiája. BKE Szociológiai és Szociálpolitikai Tanszék, Budapest, 99-129.

3. Cooper, D. - McCausland, W. D. - Theodossiou, I.: Unemployed, Uneducated and Sick: The Effects of Socio-Economic Status on Health Duration in the European Union. - Journal of Royal Statistical Society . 2008. évi 4. sz. 939-952.

4. Fábián Gergely, Huszti Éva, Hüse Lajos, Takács Péter (2018): Életminőség Nyíregyházán. A nyíregyházi nagymintás társadalomkutatások első négy hulláma a megyeszékhelyen. Szabolcs-Szatmár-Beregi Szemle 53/3: 83-102.

5. Hajdu Gábor és Sik Endre (2016): A munkával kapcsolatos értékek a világban (1990-2014) és a mai Magyarországon. In. Kolosi Tamás, Tóth István György (szerk). Társadalmi Riport. TÁRKI: Budapest.

6. Huszti Éva, (2018): Társas kapcsolatok Nyíregyházán 2008-2018. Acta Medicinae et Sociologica Vol.9. No.27. 110-124.

7. Huszti Éva, Hüse Lajos, Takács Péter, Fábián Gergely, (2018): A „Nyíregyháza Élet-minősége 2018" vizsgálat és a kutatás módszertana. Acta Medicinae et Sociologica Vol.9. No.27. 7-18.

8. Jávorné Erdei Renáta, Takács Péter, (2018): Szubjektív egészségi állapot és annak változásai Nyíregyházán. Acta Medicinae et Sociologica Vol 9., No.27. 96-109.

9. Láczay, Magdolna (2017): A humánerö fejlesztésének kérdőjelei a halmozottan hátrányos térségekben. A Virtuális Intézet Közép-Európa Kutatására közleményei, (9) 2. pp. 129-137.

10. Láczay, Magdolna (2018): A társadalmi mobilitás néhány jellegzetessége a rendszerváltás óta Szabolcs-Szatmár-Bereg megyében, Közép-Európai Közlemények: 2 pp. 7-16., (2018)

11. Móré Mariann (2018): A foglalkoztatáspolitika társadalmi és gazdasági meghatározottsága. In. Sebők Marianna (szerk). A munka világa. Saxum Kiadó, Budapest. pp. 31-50.

12. R. Fedor Anita, Fóna, Mihály (2017):A magasan kvalifikált fiatal munkavállalói csoportok elemzésének új megközelítési lehetősége: a prekariátus. Különleges bánásmód 3:4 pp. 7-17.,11 p.

13. R. Fedor Anita, Balogh Erzsébet (2015): A foglalkoztatás és a munkanélküliség jellemzői a Nyíregyházi járásban. Acta Medicinae et Sociologica 6 :18-19 pp. 47-67, $21 \mathrm{p}$.

14. R. Fedor Anita, Jávorné, Erdei Renáta (2014): A foglalkoztatás jellemzői Nyíregyházán. Acta Medicinae et Sociologica 5 : 12-13 pp. 29-46., 18 p.

15. R, Fedor Anita (2012): A gazdasági aktivitás lokális jellemzői: nők és férfiak a "munka piacán". Acta Medicinae et Sociologica 3 : ksz. pp. 83-98., 16 p. (2012) 
16. Sebők Marianna (2013): A társadalmi mobilitás elősegítése a munkaerő-piaci mobilitás támogatásán keresztül, Humánpolitikai Szemle 2013: 7-8. pp. 40-48.

17. Sebők Marianna (2015): Comments on workforce mobility in Hungary, Modern Geográfia 2015:(3.) pp. 49-67

18. Szoboszlai Katalin, (2018): A lakhatás és a háztartások felszereltségének változásai a panelkutatások eredményei alapján. Acta Medicinae et Sociologica Vol.9. No.27. 19-32. 